\title{
Technological Spillover, Growth Convergence And Technical Progress: Does Technology Flow From Rich To Poor Economies?
}

\author{
Oladele O. Aluko Ph.D \\ Department of Economics, Faculty of Social Science, \\ University of Abuja, FCT - Nigeria \\ Dr. Sani, B. Sabiu \\ Department of Economics, Faculty of Social Science, \\ University of Abuja, FCT- Nigeria
}

\begin{abstract}
This study examines Technology spillover from rich to poor countries, the study used a model that, at the aggregate level, is similar to the one sector neoclassical growth model. The model was estimated using data on technical progress, Average Product Per-Worker, Capital Stock and Technology Intensive Goods in 25 countries which consist of rich and poor countries over the last decade. A dynamic panel model is formulated and estimated Using Generalized method of moments by Arelano and Bond; and the implications of the estimates were evaluated for aggregate total factor productivity and economic growth. The results reveal that, on average, technology have contributed more to economic growth in high income economies and on the contrary technology have made little or no contribution in low income countries. Consequently, there is substantial variation across technologies and economies.
\end{abstract}

Keywords: Productivity, Economic growth, spillovers, technological transfer, technical progress

\section{INTRODUCTION}

Technological progress refers to improvements in the techniques and methods by which goods and services are produced, branded and sold in an economy (Chandra, 2006). Technological progress is at the heart of human progress and development. At the national level, technological progress can occur through invention and innovation; this is possible through the adoption and adaptation of pre-existing but new-to-the-market technologies; and through the spread of technologies across firms, individuals, and the public sector within a country. For developing economies, the bulk of technological progress occurs through the latter two channels and this has a considerable implication on economic growth.

According to Maurseth (2002) economic growth refers to the trend of the time paths for national income of a country. In recent years there has been increasing interest in economic growth and the 
forces determining countries' income levels. The increase in real GDP per capita or labour productivity (GDP per hour worked) of a country is an indicator for increases in the national income per capita or worker. The growth rates of per capita GDP or labour productivity differ significantly among countries and in time. These growth differentials matters because they have a large impact on economic welfare in the long run. In order to understand the large differences in standards of living, it is necessary to explain the deviations in long-run growth rates (Melchior and Telle, 2001). Various scholars agree on which economic forces are the most important determinants of productivity growth, such as technological change, although they have different views on how to estimate the relative impact of these forces.

Most cross-country differences in per capita output are due to differences in total factor productivity (TFP), rather than to differences in the levels of factor inputs (Diago and Bart, 2008). These cross-country TFP disparities can be divided into two parts: those due to differences in the range of technologies used and those due to non-technological factors that affect the efficiency with which all technologies and production factors are operated.

The endogenous adoption decisions determine the growth rate of productivity embodied in the technology because new production methods embody a higher level of productivity and their adoption raises the average productivity level of the production methods in use. This is what I referred to as the embodiment effect.

The importance of International technology transfer (ITT) for economic development can hardly be overstated. Both the acquisition of technology and its diffusion foster productivity and growth convergence. As invention and creation processes remain overwhelming in the province of the OECD countries, most developing countries must rely largely on imported technologies as sources of new productive knowledge. However, considerable amounts of follow-on innovation and adaptation occur in such countries. Indeed, these processes effectively drive technological change in developing nations. Developing countries have long sought to use both national policies and international agreements to stimulate ITT. National policies range from economy-wide programs (e.g., education) to funding for the creation and acquisition of technology, tax incentives for purchase of capital equipment and intellectual property rights (IPRs). According to Bernard et al (2004), a prominent episode of international efforts to encourage ITT came in the late 1970s, when many developing countries sought a Code of conduct to regulate technology transfer under United Nations (UN) auspices. It is difficult to regulate ITT effectively given the incentives for owners not to transfer technology without an adequate return and the problem of monitoring compliance with any rules that might be imposed. This explains why ITT is predominately mediated by national policies rather than by international disciplines. While some policies are subject to multilateral disciplines (e.g., subsidies, trade and IPR policies), the rules in place are primarily constraining in nature they define limits on what is allowed. Multilateral efforts to identify actions that governments should pursue to encourage international technological transfer are of common place.

Existing studies of technology spillover from previous empirical evidence are not well suited to answer the question that technology have been able to flow from rich to poor countries or not. On the one hand, macroeconomic models of technology adoption e.g Mary and Michela (2009), Mavannoor (2009) which used abstract concept of technology which is cumbersome to measure, 
Aluko, O. O., \& Sani, B. S. (2020) Technological Spillover, Growth Convergence and Technical Progress: Does technology flow from rich to poor economies? Archives of Business Research, 8(4). 132-145.

quantify and analysed. On the other hand, the applied microeconomic technology diffusion literature (Walz 2015, Wang 2010) involves the estimation of diffusion curves for a relatively small number of technologies and countries. These diffusion curves, however, are purely statistical descriptions which are not embedded in an aggregate model. Hence, it is difficult to use them to explore the aggregate implications of the empirical findings. There is a need to examine the extent to which technological spillover have occurred across international boundary flowing from rich to poor countries.

This paper bridges the gap between these two literatures by developing a new model of technology spillover. The model has two main properties. First, at the aggregate level it is similar to the one sector neoclassical growth model. Second, at the disaggregate level it has implications for the path of observable measures of technology adoption. These properties allow for model estimation using data on specific technologies and then calibrating the implications of our estimates for aggregate TFP and per capita income. This paper explores the importance of the range of technologies used to explain cross-country differences in TFP and its effect on growth. Consequently the objectives of the study include;

I. Explore the extent of the success of technical spillovers across economic diversities

II. To explores the importance of the range of technologies in relation to the TFP

III. To explain cross-country differences in TFP and its effect on economic growth.

The study is organised into six sections, starting with the introduction and objectives of study, literature review, theoretical considerations on technological spillover and growth convergence, methodology, estimation and findings and finally, the concluding remarks.

\section{EMPIRICAL EVIDENCE ON TECHNOLOGICAL SPILLOVER AND GROWTH CONVERGENCE}

In the past forty years, many economists have conducted research on what influences technology level in different countries and thereby economic growth (see e.g., Barro and Sala-Martin (1991, 1995) and Mankiw et al(1992)). These researches pointed mainly towards three different factors that influence economic growth and convergence: technology transfers, technology spillovers and technology diffusion. Obviously, there are large gaps between levels of technology across countries and in particular developing countries which makes a lot of efforts to minimise this gaps.

Convergence is one of the most studied topics in the growth literature. A first approach explains convergence as a result of decreasing returns in physical or human capital accumulation. This is the neoclassical approach pioneered by Solow (1956) and subsequently developed by Barro and Sala-Martin $(1991,1995)$ and Mankiw et al (1992). A second approach explains convergence as resulting primarily from cross-country technological spillovers. Namely, innovations in one sector or one country often build on knowledge that was created by innovations in another sector or country. The process of diffusion, or technology spillover, is an important factor behind crosscountry convergence. Howitt (2000) showed how this can lead to cross-country conditional convergence of growth rates in Schumpeterian growth models. Specifically, a country that starts far behind the world technology frontier can grow faster than one close to the frontier because the former country will make a larger technological advance every time one of its sectors catches up to the global frontier. In Gerschenkron's (2002) terms, countries far from the frontier enjoy an 'advantage of backwardness'. This advantage implies that in the long run a country with a low rate of innovation will fall behind the frontier but will grow at the same rate as the frontier; as they fall 
further behind, the advantage of backwardness eventually stabilises the gap that separates them from the frontier.

Indeed, King and Levine (1993) provided strong evidence that technical development is important for capital accumulation, economic growth, and productivity gains. Subsequent research by King and Levine (1994) suggests that differences in productivities, and not factor supplies, are likely to explain differences in incomes across countries. This sentiment is echoed by Prescott (1998), who calls for a theory of TFP. Such differences in productivities can emerge from differences in technology adoption, which may in turn be affected by disparities in technical development.

Rivera-Batiz and Romer (1991) discuss the implications of economic integration in this context. They show that with nationally bounded technology spillovers, international trade may not increase growth rates, though static efficiency gains from trade remain. If integration increases the knowledge base used in research in each country, however, integration might well increase longrun growth rates.

Lucas (1988) and Young (1991) are two examples of growth models in which divergence occurs because of bounded spillovers and where divergence will typically be more pronounced when countries integrate. Lucas builds on Krugman (1986) and develops the framework of dynamic comparative advantages in which spillovers are confined to industries. Countries specialise their production in the sectors in which they have a (static) comparative advantage. Productivity evolves over time as a function of aggregate past production. If some industries happen to have a potential for higher productivity growth than others, countries specialised in these industries will experience higher growth rates than other countries do. This opens the possibility for diverging economic development.

In the simplest models of endogenous growth, spillovers are thought of as an automatic effect of production or investments. There is a large set of models that refine the concepts of technological change and knowledge spillovers. In several models, research activities are introduced as a distinct economic sector (see, for instance, Romer, 1990).

In Romer's model, there are dynamic increasing returns in the $R \& D$ sector generated by technological spillovers. In particular, it is assumed that the R\&D sector employs researchers who make use of aggregated knowledge available in the economy. Their products are new blueprints, but their research also adds to society's knowledge stock. By steadily increasing productivity in the research sector, unbounded growth is made possible through knowledge spillovers. Romer's model does not predict convergence. Growth will be an increasing function of the workforce employed in R\&D and of aggregated knowledge. Romer's model predicts dynamic effects of economic integration in two different ways: First, by trade an economy gets access to a larger flow of new varieties. This generates higher growth in consumption. Second, economic integration allows national researchers to draw on a larger knowledge base in their research. This is expected to increase their efficiency.

Aghion and Howitt (1992 and 1998), Klette and Griliches (1998) and Barro and Sala-Martin (1995) take into account the genuine uncertainty of technological change. Instead of modelling research as a deterministic process, it is assumed to be a stochastic process. Innovations are modelled as a 
Aluko, O. O., \& Sani, B. S. (2020) Technological Spillover, Growth Convergence and Technical Progress: Does technology flow from rich to poor economies? Archives of Business Research, 8(4). 132-145.

Poisson process in which the arrival rate of innovations is assumed to be an increasing function of investments in R\&D. The R\&D models formalise older ideas of Joseph Schumpeter on creative destruction. Drastic innovations force out older vintages of goods and increasing wages due to increased productivity crowd out older goods as time passes.

An interesting extension by Howitt (2000) is a model in which researchers' efficiency draw on an existing international knowledge base, but in which some countries do not do R\&D. Howitt's model demonstrates how a country's position at the world income ladder may depend on own resources spent on R\&D and of subsids to R\&D. For some parameter values, countries will not invest at all, in which case there is no growth.

More recently, Ciruelos and Wang (2015) look at a sample of 47 OECD and developing countries from 1998 to 2001. They concluded that both FDI and trade serve as a channel for technology diffusion in developing countries that possess a critical mass of both human capital and latest technology. To conclude, the major part of the empirical research reveals that FDI has positive effect on labor productivity throughout technology spillovers.

Xu and Chiang (2016) use a sample of 48 countries for the period 2000 to 2014. Technological spillover in this study mainly consists of domestic patents, foreign patents and import share. They shared the sample in three groups according to the real GDP per capita. They found that all countries enjoy technology benefit by learning from foreign technology. Ciruelos and Wang (2015) investigate data from 57 countries from 2001-2013 found that "bilateral trade among DCs and exports from DCs to LDCs have a positive effect on the importing country's productivity through R\&D diffusion."(Ciruelos and Wang, 2015).

Zhang and He's (2014) employed a panel of 47 countries (include 20 developed countries while the rest are developing countries) over the period 1995 to 2012 and focused on relations between TFP (Total factor productivity) and R\&D, Import, FDI. Zhang and He's (2014) reported that the elasticity of TFP with respect to trade remain positive and highly significant; the elasticity of TFP with respect to FDI serves as a channel for international spillovers; and the elasticity of TFP with respect to the domestic stock of R\&D has a significant and positive impact in all specifications. To summarize the results, productivity of one country especially a developing nation has a strong 1 Total-factor productivity (TFP) is a variable which accounts for effects in total output due to the combination of production factors inputs. If all inputs are accounted for, then total factor productivity (TFP) can be taken as a measure of an economy's long-term technological change or technological dynamism.

Liu (2013) empirical evidence on R\&D spillovers across countries is a seminar contribution in this direction. The relationship between total factor productivity and domestic and foreign knowledge capital stock has been examined in a sample of 22 industrial economies during the period 1991 to 2010. They have found that accumulated spending on R\&D by a country and by its trade partner helps to explain the growth of total factor productivity. The most important finding of the study is that the foreign R\&D capital stock, that is externality, has particularly large effects on the smaller countries. 
Evenson and Englander (2014) have enlarged the scope of their analysis to use information at sectorial level for eleven OECD countries and examined the relationship between TFP and domestic and foreign knowledge capital stock. They have found that the impact of foreign R\&D stock is relatively low for the leader country where little R\&D spilling is occurring. For the mean country and industry the R\&D elasticities are almost similar to domestic elasticities. Developing countries are apparently placed in a disadvantageous position in terms of 5 innovations and inventions.

Coe, et al, (2015) in an important empirical study, which is based on observations over the 20002012 period for 77 developing countries, suggest that spillover from the developed industrial countries to the developing countries are substantial. However, in their study they have completely ignored the impact of domestic R\&D stock on total factor productivity of economies on the pretext of non-availability of reliable data. It has been argued in technological capability literature that the developing countries must invest in R\&D to acquire the technical capability needed to make use of the public domain knowledge to enhance its productivity (Cohen and Levinthal, 2012; Fransman and King, 2014). Thus, it is amply clear that international R\&D spillovers will not contribute to productivity gains until developing countries invest in R\&D.

The ability of poorer countries to make use of technology developed elsewhere is a function not only of the rate of innovation at the technological forefront, but is also assumed to depend on their own absorptive capacity and their technological congruence (Abramowitz, 1994). Thus, it is expected that the extent to which poorer countries make use of technology flows from more advanced countries is a function of these poorer countries' institutions, history, social conditions to mention but few. Among other factors, the level of education and human capital is assumed to be a decisive factor. This is a consequence of the assumption that technology flows are not only outdated blueprints, but also a source of new technological development. Thus, catch-up is viewed as a process in which poorer countries both imitate and adapt older technology.

\section{THEORETICAL ANALYSIS ON GROWTH CONVERGENCE AND TECHNOLOGICAL SPILLOVER}

Science, Technology and Innovation (STI) are critical to economic and social engineering (Aluko and Adolphus, 2019). Theories of technology gaps incorporate Posner's and Vernon's theories on economic development (Posner, 1961; Vernon, 1966) into a Schumpeterian view on innovation and imitation. The idea is that new technology is developed in certain countries that are constantly at the technological forefront. The countries at the forefront have the role of developing new products or improving their quality. At the first stage in a product's cycle, there are well-defined property rights on the product's technology. Later on in the product cycle, the production of the good is relocated to other countries. This may be the effect of two independent factors. First, as the advanced country keeps on innovating, older vintages produced under less efficient technology get crowded out because of increasing wages in the frontier country.

Second, as a technology grows old, it gets increasingly harder to appropriate its returns. As time passes, the technology becomes a public good. As a consequence of these conditions, other countries further down on the productivity ladder take over production of the older vintages.

Thus, technology gap theories on economic growth take productivity increase at the forefront as given. The focus is on diffusion of technology. Technology gap theories are therefore theories of very conditional convergence: Through diffusion, poorer countries are able to catch up with the 
Aluko, O. O., \& Sani, B. S. (2020) Technological Spillover, Growth Convergence and Technical Progress: Does technology flow from rich to poor economies? Archives of Business Research, 8(4). 132-145.

world economic leaders. Productivity increases at the forefront, however, increases the length of the ladder to climb.

Krugman (1979 and 1986) presents models in which it is demonstrated that productivity increase at the forefront is always to the benefit of both rich and poor countries while catch-up is a benefit for poorer countries, but not necessarily for richer ones. In Krugman (1979) the crowding out effect is formalised, in Krugman (1986) the diffusion effect is analysed. Fagerberg (1988) presents models in which growth in a set of countries is assumed to be a function of technological distance between the country in question and the world economic leader (the US) and resources devoted to increase the country's absorptive capacity. Fagerberg demonstrates that the outcome of economic development might be both convergence and divergence. Fagerberg proposes that a country's income level will depend on own $R \& D, R$, diffusion of knowledge from abroad, $Q$, the countries capacity for exploiting knowledge, $\mathrm{C}$, and a constant

$$
\begin{gathered}
\mathrm{Y}=\mathrm{ZQ}^{\mathrm{a} \mathrm{R}^{\mathrm{b}} \mathrm{C}} \\
\frac{Y \cdot}{Y}=\frac{a Q}{Q}+\frac{b R}{R}+\frac{e C}{C}
\end{gathered}
$$

The technology gap hypothesis is that countries lagging far behind the frontier have a larger potential for catch-up than other countries. The frontier is supposed to be indicated by knowledge in the leading economy in the world, $Q^{*}$. Therefore:

$$
\frac{Q}{Q}=h-h\left(\frac{Q-Q}{Q}\right)
$$

Growth will now be given by the expression:

$$
\frac{Y}{Y}=a h-a h \frac{Q}{Q}+\frac{b R}{R}+\frac{e C}{C}
$$

The empirical implications of this model are very similar to empirical formulations of the neoclassical growth model. In the technology gap models, poor countries are predicted to have a high potential for growth through technology imports, in neoclassical models, they are predicted to grow fast because of high returns to capital.

Verspagen (1991) models catch-up and technology flows in a similar way. Verspagen explicitly opens up for the existence of underdevelopment traps. For countries being way behind the technological leader, the ability to make use of technology flows is limited. Other countries, ranging further up on the productivity ladder, have higher absorptive capacity and are able to keep constant or reduce the technology gap. Thus, Verspagen's model predicts a world in which there is a club of very poor countries and another club of converging wealthy countries. 


\section{Measurement of Technical Progress}

\section{METHODOLOGY}

TFP is interpreted as a measure of the technology of production and its rate of growth as a measure of technical progress in an economy. Assume an open economy where output is produced using capital $(K)$ and labor $(L)$ via a neoclassical production function.

$$
Y_{t}=A_{t} F\left(K_{t}, L_{t}\right)=A_{t} K_{t}{ }^{\alpha} L_{t}{ }^{1-a}
$$

Where $Y$ denotes output and $A$ is the productivity parameter (technical Progress). Agents can borrow and lend resources internationally. If all countries share a common technology, perfect capital mobility implies the instantaneous convergence of the interest rates. Hence, for countries iand $j$,

Note:

$$
F^{0}(.)>0, F^{00}(.)<0, F(0)=0
$$

Fulfils Inanda's Condition

$$
A_{t} f^{1}\left(k_{i t}\right)=r t=A_{t} f^{1}\left(k_{j t}\right),(4.3)
$$

wheref(.) is the net of depreciation production function in per capita terms. The property of diminishing returns to capital implies that in the transition process, resources will flow from capital abundant countries (low returns) to capital scarce countries (high returns). Although widely used in the growth literature, the neoclassical model has counterfactual implications for rates of returns since not enough capital seems to flow to capital scarce countries and implied interest rates do not seem to converge.

According to Upadhyay (2000) technical Progress is measured as Solow's Residual from the neoclassical growth model. Linearizing equation 4.1 gives;

$$
\ln Y=\ln A+\alpha \ln K+(1-\alpha) \ln L(4.4)
$$

Such that ln represent Natural Logarithm

From equation (4.4)

$$
\ln \hat{A}=\ln \hat{Y}-\alpha \ln K+(1-\alpha) \ln L(4.5)
$$

Taking the antilog of $\ln \hat{A}$ we derive A which is the Total Factor Productivity (TFP) a measure of technical progress.

\section{Study Area}

This study covers high income OECD countries, High income - non OECD countries, Upper /Middle income countries, Middle /low income countries and low income countries. Five (5) countries are selected from each income group. For high income OECD countries the countries selected are Switzerland, United State, France, Germany and Japan. For high income non OECD countries they are Russia, Hong Kong, Argentina, Cyprus and Saudi Arabia. For Upper/Middle income countries 
they are Serbia, Libya, Jordan, South Africa and Brazil. For Middle /low income countries they are Nigeria, Cameroon, Cape Verde, Georgia and Sri Lanka. For low income countries they are Niger, Nepal, Gambia, Chad and South Sudan. This make up a panel of twenty five (25) countries under consideration. The study is made up of balance panel where the observations for each countries is from 2010 to 2016.

\section{Model Specification}

The relative impact of technology on economic growth on each category of country will be used to examine if technology and technical progress have move across international boundary. To examine the impact of technology on economic growth a dynamic panel model is formulated which is similar to that of Klein (2003), who studied "Capital Account Openness and the Varieties of Growth Experience". The model is given as;

$$
E G_{i t}=\alpha 0+\sum_{j=1}^{m} \delta_{i j} T P_{i t-j}+\sum_{j=1}^{m} \lambda_{i j} A P L_{i t-j}+\sum_{j=1}^{m} \beta_{i j} K S_{i t-j}+\sum_{j=1}^{m} \gamma_{i j} T I G_{i t-j}+U_{i t}
$$

Where;

EG is Economic Growth (given as the rate of change of Real GDP measured in dollars)

TP is technical Progress (Solow's Residual)

APL is Average Product Per-Worker (measured as the ratio of total output per workers employed) $\mathbf{K S}$ is Capital Stock available in the economy given as Gross Fixed Capital Formation

TIG is Technology Intensive Goods (Technology intensive goods are defined on the basis of R\&D intensity).

EG is given as the rate of change of Real GDP measured in dollars, APL is measured as the ratio of total output per workers

The model is estimated using the Panel Generalized Method of Moment by Arelano and Bond (1986). Panel Generalized Method of Moment is consistent and robust among other class of Dynamic Panel estimators. The estimated parameters are calibrated based on prior knowledge and empirical evidence to get the best fit of the data collected.

\section{ESTIMATION OF PARAMETERS}

The result presented are based on the model in equation 4.6 estimated using GMM dynamic panel data technique by Arelano and Bond (year). The result is given as follows; 
Table 4.1: GMM Result Indicating Each Income Group

\begin{tabular}{|c|c|c|c|c|}
\hline Income Group & TP & APL & KS & TIG \\
\hline $\begin{array}{c}\text { High Income } \\
\text { OECD } \\
\text { Countries }\end{array}$ & 77.3452 & 11.3212 & 34.0145 & 83.4051 \\
\cline { 2 - 5 } & $(8.0921)^{* *}$ & $(3.0921)^{* *}$ & $(6.1652)^{* *}$ & $(15.1742)^{* *}$ \\
\hline \multirow{2}{*}{$\begin{array}{c}\text { High Income } \\
\text { Non-OECD } \\
\text { countries }\end{array}$} & 31.6211 & 25.1543 & 35.1543 & 44.2218 \\
\cline { 2 - 5 } & $(9.1665)^{* *}$ & $(6.2209)^{* *}$ & $(9.1907)^{* *}$ & $(12.2459)^{* *}$ \\
\hline $\begin{array}{c}\text { Upper/Middle } \\
\text { Income }\end{array}$ & 25.0821 & 17.9203 & 21.9202 & 35.2155 \\
\cline { 2 - 5 } Countries & $(5.2910)^{* *}$ & $(3.0151)^{* *}$ & $(4.2212)^{* *}$ & $(12.2269)^{* *}$ \\
\hline $\begin{array}{c}\text { Middle/Low } \\
\text { Income }\end{array}$ & 5.0094 & 1.3209 & 4.0112 & 3.2112 \\
\cline { 2 - 5 } Countries & $(4.2441)^{* *}$ & $(0.0922)^{* *}$ & $(1.1632)^{* *}$ & $(2.2215)^{*}$ \\
\hline \multirow{2}{*}{$\begin{array}{c}\text { Low Income } \\
\text { Countries }\end{array}$} & 2.3094 & 4.3430 & 0.3123 & 0.0941 \\
\cline { 2 - 5 } & $(1.7395)^{*}$ & $(0.0921)^{* *}$ & $(0.1652)^{*}$ & $(0.0891)^{*}$ \\
\hline
\end{tabular}

Notes: () are wald statistics for test of significance of Parameters, ${ }^{* *}$ signifies that the parameter is significant at $5 \%$ and * signifies that the parameter is insignificant; Country groups are as defined by World Bank. Technology Intensive Goods (TIG) are defined on the basis of R\&D intensity. Data used are from UN COMTRADE database (trade); IMF Balance of Payments statistics (royalties) and UNCTAD, World Investment Report.

Source: Author's Computation 2017

From the Result, an increase Technical progress account for 77 unit increase in Economic growth for High Income OECD countries. Technical progress account for 31 unit increase in Economic growth for High Income non OECD countries, this is lower than its impact in OECD countries. For Upper/Middle income countries, technical progress account for 31 unit increase in Economic growth. For Middle/low income countries, technical progress account for 5 unit increase in Economic growth. Finally, for Low income countries, technical progress account for 2 unit increase in Economic growth and this increment is statistically insignificant for only low income countries.

An increase in Average Product of Labour account for 11 unit increase in Economic growth for High Income OECD countries. Average Product per Worker account for 25 unit increase in Economic growth for High Income non OECD countries, this is lower than its impact in OECD countries. For Upper/Middle income countries, Average Product per Worker account for 17 unit increase in Economic growth. For Middle/low income countries, Average Product per Worker for 1 unit increase in Economic growth. Finally, for Low income countries, Average Product per Worker account for 4 unit increase in Economic growth and this increment is statistically significant for all income level.

An increase Capital Stock account for 34 unit increase in Economic growth for High Income OECD countries. Capital Stock account for 35 unit increase in Economic growth for High Income non OECD countries, this is higher than its impact in OECD countries. For Upper/Middle income countries, Capital Stock account for 21 unit increase in Economic growth. For Middle/low income 
Aluko, O. O., \& Sani, B. S. (2020) Technological Spillover, Growth Convergence and Technical Progress: Does technology flow from rich to poor economies? Archives of Business Research, 8(4). 132-145.

countries, Capital Stock account for 4 unit increase in Economic growth. Finally, for Low income countries, Capital Stock account for 0.3 unit increase in Economic growth and this increment is statistically insignificant for only low income countries.

Technology Intensive Goods (TIG) account for 83 unit increase in Economic growth for High Income OECD countries. Technology Intensive Goods (TIG) account for 44 unit increase in Economic growth for High Income non OECD countries, this is lower than its impact in OECD countries. For Upper/Middle income countries, Technology Intensive Goods (TIG) account for 35 unit increase in Economic growth. For Middle/low income countries, Technology Intensive Goods (TIG) account for 3 unit increase in Economic growth this increment is statistically insignificant for middle/low income countries. Finally, for Low income countries, Technology Intensive Goods (TIG) account for 0.09 unit increase in Economic growth and this increment is statistically insignificant for low income countries.

\section{Stylized Facts}

Table 4.2: Disparity among TFP

\begin{tabular}{|l|c|c|}
\hline \multicolumn{1}{|c|}{ Regions } & $\begin{array}{l}\text { TFP as a \% of } \\
\text { Total Output } \\
\mathbf{( 2 0 1 6 )}\end{array}$ & $\begin{array}{l}\text { Percentage } \\
\text { Change in TFP } \\
\text { from 2010- } \\
\mathbf{2 0 1 6}\end{array}$ \\
\hline East Asia and the Pacific & 8.4 & 5.1 \\
\hline Europe and Central Asia & 21.7 & 2.2 \\
\hline Latin America and the Caribbean & 19.3 & 0.2 \\
\hline Middle East and North Africa & 13.3 & 0.5 \\
\hline South Asia & 5.8 & 2.3 \\
\hline Sub-Saharan Africa & 5.6 & 0.2 \\
\hline & $\begin{array}{c}\text { TFP as a \% of } \\
\text { Total Output } \\
\mathbf{( 2 0 1 6 )}\end{array}$ & $\begin{array}{c}\text { Percentage } \\
\text { from 2010- } \\
\text { from } \mathbf{2 0 1 6}\end{array}$ \\
\hline High-income OECD Countries & 72.1 & 1.3 \\
\hline High-income non-OECD Countries & 53.1 & 0.7 \\
\hline Upper-middle-income Countries & 23.7 & 1.2 \\
\hline Lower-middle-income Countries & 9.6 & 3.2 \\
\hline Low-income Countries & 5.2 & 1.7 \\
\hline
\end{tabular}

Source: Economic Global Prospect 2017.

Note: OECD Organisation for Economic Co-operation and Development; TFP total factor productivity

International comparisons of TFP suggest that vast gaps exist between high- income and low-and middle-income countries in the efficiency with which they produce goods and services (table 4.2). In 2016, the average level of TFP in low-income countries was only 5 percent of total output. The technology lower-middle- income countries employed was roughly twice as efficient and that of upper-middle-income countries was approximately four times as efficient. While these gaps have been narrowing for low-income and lower-middle-income countries, upper-middle-income countries have only managed to maintain their relative position in relation to high-income 
countries. At the regional level, these gaps have widened or remained stagnant in three of six developing regions, with TFP growing faster in high- income countries than in Latin America and the Caribbean, the Middle East, and Sub- Saharan Africa.

\section{Data versus Model}

This section examines the model estimates against data values, it is necessary to compare the result estimates against the observed figures to identify the disparities between the actual and estimated values.

Table 4.3:Technology Intensive Goods (TIG) Contribution to Economic Growth based on 2016 Data and Estimated Model

\begin{tabular}{|c|c|c|}
\hline Income Groups & Data & Model \\
\hline High Income OECD Countries & 75.1 & 83.3 \\
\hline High income non-OECD Countries & 32.1 & 44.2 \\
\hline Upper-middle-income Countries & 15.7 & 25.2 \\
\hline Lower-middle-income Countries & 5.6 & 5.2 \\
\hline Low-income Countries & 1.2 & 0.09 \\
\hline
\end{tabular}

Source: Economic Global Prospect 2017. Author's Computation 2017

From Table 4.3, for high income Groups the difference between parameter estimates and the model is 8.1, however the contribution of Technology Intensive Goods to economic growth is high. For High income non OECD countries the disparity between Data and model estimates is 12.1 and the contribution of Technology Intensive Goods to economic growth is relatively lower to that of High income OECD countries. For Upper- Middle income group the disparity between data and model is 9.5 and the contribution of Technology Intensive Goods to economic growth is low. For low-middle income group the difference between data and model estimates is 0.4 indicating that data and model estimate converges for this income group, nonetheless, the contribution of Technology Intensive Goods to economic growth is very low. Finally for low income group the disparities between data and model is 1.11 and the contribution of Technology Intensive Goods is virtually absence.

\section{CONCLUSION AND IMPLICATIONS}

It is a challenge to draw together all the different strands covered in this paper, but this will be attempted here. From the findings it is obvious that technology have not flown from the rich to the poor countries as there is still a considerable disparity between technology and technical progress in High income OECD countries and Low income countries. Also, the study have revealed that the impact of technical progress on economic growth is not constant for all income groups. Technical progress contribute more to economic growth in High income groups than in low income groups. Again, average product of labour is relatively low in low income group and high in the high income group. Technology Intensive Goods are fewer in low income groups and much in high income groups. The findings of this study have refuted the convergence hypothesis while it has shown that the gap between the rich and poor economies is like a brick wall which continues to expand. These realities will question the activities of international agencies and agreement on technology transfer 
Aluko, O. O., \& Sani, B. S. (2020) Technological Spillover, Growth Convergence and Technical Progress: Does technology flow from rich to poor economies? Archives of Business Research, 8(4). 132-145.

and even development as these agencies and their activities have not been able to ensure growth convergence rather fostering disparities between rich and poor economies through international agreement, regulations and policies aimed at promoting the interest of high income economies at the detriment of low income ones.

However, to foster technologically inclined growth in developing countries several measures have to be put in place, this includes; Developing countries have to take their destiny in their own hands by committing more funds to $R \& D$ to unlock indigenous technology which have the capacity to improve productivity and utilize local content.

Also, the education system and structure should be re-evaluated and restructured to incorporate more technical and technological based training and be less theoretical oriented.

Finally, Globalization and the positivities should be embraced by developing economies as they are channels on which technology flows among countries. Given that wages in developing economies are relatively low compared to those of developed ones, conducive environment have the potential to motivate technologically inclined multinationals to expand operations in developing economies consequently reduce average cost per labour $\left(\mathrm{AC}_{\mathrm{L}}\right)$ and minimize cost.

\section{References}

Abramovitz, M. (1956). 'Resources and Output Trends in The United States since 1870', American Economic Review, 46, 5-23.

Abramovitz, M. (1994). 'Catch-up and Convergence in the Postwar Growth Boom and After' in Journal of International Economics, 13, 105-162.

Aghion, P. and P. Howitt (1992). 'A Model of Growth through Creative Destruction', Econometrica, 60, 323-51.

Aghion, P. and P. Howitt (1998). Endogenous Growth Theory, The MIT Press, Cambridge, Massachusetts.

Aluko, O. O. and J. A. Adolphus (2019). 'The role of Technology innovation in public health Management'. Being paper presented at the 2nd International Conference on Economics, Management and Technology (IEMT 2019) held at Hochschule Neu - Ulm, Nov. 19th - 21st, University of applied science (HNU), Neu - Ulm, Germany

Barro, R. J. and X. Sala-I-Martin (1995). Economic Growth, McGraw-Hill, New York.

Basu, P. and Weil, I. (1998). Endogenous Growth Theory, The MIT Press, Cambridge, Massachusetts.

Caselli, D. T. and Helpman, Coleman (2006). 'International R\&D spillovers', European Economic Review, 39, 859-87.

Chandra, A. (2006). 'North South R\&D Spillovers', Economic Journal, 107, 134-149.

Ciruelos L., and Wang S., (2015). International R\&D spillovers and manufacturing productivity: A panel data analysis, Structural Change and Economic Dynamics, vol19, issue2, 152-72.

Coe C., Riccardo L. and Anna M., (2015). Spatial knowledge spillovers and regional productivity growth in Europe, Univerisity of Bari and CERIS-CNR, 201-21.

Diago, D. and Bart, H. (2008). 'A Technology Gap to Why Growth Rates Differ', Research Policy, 16, 87-99.

Evenson, G. and Englander, T. (2014). Foreign Direct Investment and Spillovers Through Workers' Mobility, Journal of International Economics, 53, 205-222.

Fagerberg, J. (1988). Technology, Growth and Trade - Schumpeterian Perspectives D- phil thesis, Sussex.

Gerschenkron, K. (2002). Innovation and Growth in the Global Economy, The MIT Press, Cambridge, Massachusetts. 
Howitt, P. (2000). 'Endogenous Growth and Cross-Country Income Differences', American Economic Review, 90, 4, $829-46$.

King and Levine, W. (1994). 'Geographic Localization of International Technology Diffusion', American Economic Review, 92 (1), 120-42.

Klette, T. J. and Z. Griliches (1998). Empirical Patterns of Firm Growth and R\&D Investments: A Quality Ladder Model Interpretation Memorandum from Department of Economics, University of Oslo, No 23.

Krugman, P. (1979). 'A Model of Innovation, Technology Transfer and the World Distribution of Income', Journal of Political Economy, 87, 2, 253-66.

Krugman, P. (1986). 'A 'Technology Gap’ Model of International Trade in Jungenfelt, K. and D. Hauge (ed.) Structural Adjustment in Advanced Economies, Macmillan, NewYork, 35-49.

Liu, (2013). Foreign direct investment and technology spillovers: Theory and evidence, Journal of Development Economics. 176-93.

Lucas, R. E. Jr. (1988). 'On the Mechanics of Economic Development', Journal of Monetary Economics, 22, 3-42.

Mankiw, N. G., D. Romer and D. N. Weil (1992). 'A contribution to the empirics of economic growth', Quarterly Journal of Economics, 107, 2, 407-37.

Mary O., Michela V., (2009). R\&D, knowledge spillovers and company productivity performance. Research Policy, 38(1), 35-44.

Maurseth, P. B. (2002). Geography and growth - some empirical evidence, NUPI Working Paper 623, Oslo.

Mavannoor P., (2009). International Trade, R\&D spillovers and productivity: Evidence from Indian Manufacturing Industry, 2008, Journal of Development Studies, 1251.

Melchior, A. and K. Telle (2001). 'Global Income Distribution 1965-98: Convergence and Marginalisation', Forum for Development Studies, 28, 1, 75-98.

Parente, P. B. and Prescott, M. (1994). 'Geography, Technology and Convergence', Structural Change and Economic Dynamics, 12, 247-276.

Posner, M. V. (1961). 'International Trade and Technical Change', Oxford Economic Papers, 13, 323-41.

Prescott, L. (1998). 'Convergence Big Time', Journal of Economic Perspectives, 11, 3-17.

Rivera-Batiz, L. A. and P. M. Romer (1991). 'Economic Integration and Endogenous Growth', Quarterly Journal of Economics,106, 531-56.

Romer, P. M. (1990). 'Endogenous Technological Change', Journal of Political Economy, 98, 71-102.

Solow, R. (1956). 'A Contribution to the Theory of Economic Growth', Quarterly Journal of Economics, 70, 65-94.

Verspagen, J. (1991). 'Growth and Interdependence', Quarterly Journal of Economics, 112, 57-84

Vernon, R. (1966). 'International Investment and International Trade in the Product Cycle', Quarterly Journal of Economics, LXXX, 190-207.

Walz, U., (2015).Innovation, Foreign Direct Investment and Growth. Economica 64: 63-79.

Wang, J.-Y., (2010). Growth, Technology Transfer, and the Long-run Theory of International Capital Movements. Journal of International Economics 29 (3-4): 255-71.

Xu, B. and E. Chiang, (2016). Trade, patents and international technology diffusion. Journal of International Trade and Economic Development 14 (1): 115-135.

Young, A. (1991). 'I Just Ran Two Million Regressions', American Economic Review, Papers and Proceedings, 87, 17883.

Zhang J., and He Y., (2014). Theoretical and Empirical Study on the Impact of Trade and Foreign Direct Investment on Technological Spillovers. Linnaeus University, 218 